\title{
Menangkap Dimensi Profan Hukum Pidana Islam dan Relevansinya Bagi Pembangunan Hukum Nasional
}

\author{
Junaidi Abdillah \\ Universitas Islam Negeri Walisongo Semarang \\ Email: junaidiabdillah02@gmail.com
}

\begin{abstract}
Abstrak
Kendati secara yuridis-formal keberadaan Hukum Pidana Islam telah menjadi sub-sistem hukum nasional, namun upaya transformasinya masih menjadi isu kontroversial. Diakui, rumusan bentuk-bentuk hukuman dalam pidana Islam hingga saat ini masih menjadi medan perdebatan di kalangan ahli. Hal ini beerimbas pada sulitnya transformasi hukum pidana Islam ke dalam Hukum Pidana Nasional. Paper ini hendak mencari jawaban dari pertanyaan: (1) Mengapa eksistensi Hukum Pidana Islam sulit ditransformasikan ke dalam HPN? (2) bagaimana peta perdebatan teori di kalangan ahli tentang Hukum Pidana Islam di Indonesia? Dan (3) bagaimana pendekatan tepat kaitanya dengan basis filosofis dalam transformasi hukum pidana Nasional? Tulisan ini menggunakan pendekatan normatif-filosofis. Penulis menggunakan unsur-unsur metodis umum seperti deduktif-induktif dan refleksi kritis pribadi dalam menganalisis. Pada akhir paper ini dirumuskan beberapa kesimpulan: (1) Terdapat sejumlah variabel yang menjadi hambatan transformasi pidana Islam ke hukum nasional yaitu: budaya, sosial dan problem keilmuan yang belum selesai di kalangan ahli terkait hukuman-hukuman pasti dalam pidana Islam. (2) Secara keilmuan para ahli dalam memandang materi hukum pidana Islam terdiametral dalam dua kutub. Sebagian memandang hukum pidana Islam dengan beberapa bentuk pidanya bersifat pasti dan sakral dengan demikian ia konstan dan sebagian lagi memandang rumusan pidana Islam merupakan entitas yang terbuka dengan pembaruan; (3) Metode yang tepat dalam memformalkan pidana Islam adalah dengan "membangun ulang" rumusan keilmuan pidana Islam yang berkarakterkan keindonesiaan dan pada saat yang sama harus memanfatkan nalar kritis yang meniscayakan pelibatan akal publik dan pendekatan multidisipliner sehingga ia menjadi relevan untuk menjadi hukum nasional.
\end{abstract}

Kata Kunci: Transformasi, Hukum Pidana Islam, Teori Pemidanaan, Pembaruan, Multidisipliner Approach.

\section{Pendahuluan}

Bangsa Indonesia kaitannya dengan pembangunan hukum nasional, menempuh kebijakan untuk menjadikan tiga sistem hukum yang ada yaitu hukum 
adat, hukum Islam dan hukum Barat sebagai bahan baku pembangunan dan pembentukkan hukum nasional (Arifin 1996, 39-40). Ketiganya secara yuridisformal telah diakui menjadi pranata yang tumbuh dalam masyarakat Indonesia dan diharapkan mampu berkontribusi bagi pembangunan hukum nasional (Asshiddiqy 1996, 5). Dalam perjalanan sejarahnya, hukum Islam telah banyak bertransformasi menjadi hukum nasional.

Lahirnya berbagai peraturan perundang-undangan baik dalam bidang perdata, peradilan agama, perbankan syari'ah (mu'amalah), perwakafan dan perzakatan merupakan bukti nyata bahwa hukum Islam telah mampu menjadi hukum nasional (Rofiq 2001, 99-101). Sebut saja (1) UU Nomor 1 Tahun 1971 tentang Perkawinan, (2) PP Nomor 28 Tahun 1977 tentang Perwakafan, (3) UU Nomor 7 Tahun 1989 tentang Peradilan Agama, (4) UU Nomor 7 Tahun 1992 jo. UU Nomor 10 Tahun 1998 dan UU Nomor 23 Tahun 1999 tentang Sistem Perbankan Nasional yang mengizinkan beroperasinya Bank Syariah, (5) Inpres Nomor 1 Tahun 1991 tentang Kompilasi Hukum Islam, (6) UU Nomor 17 Tahun 1999 tentang Penyelenggaraan Haji, dan (7) UU Nomor 38 Tahun 1999 tentang Pengelolaan Zakat, UU Peradilan Perluasan Komptensi Peradilan Agama dan lain-lainnya.

Transformasi hukum Islam menjadi hukum Nasional diakui telah mengalami perkembangan dan kemajuan yang cukup signifikan (Rofiq 2001, 99-101). Namun, kesuksesan di atas tidak berbanding lurus dengan keberadaan Hukum Pidana Islam. Upaya-upaya transformasinya diakui tidaklah semudah dalam bidang-bidang perdata (hukum keluarga) dan mua'amalat. Padahal, kebijakan hukum pemerintah telah mengakui keberadaan hukum pidana Islam sebagai bahan baku pembentukan atau pembangunan hukum pidana nasional. Idealnya, sebagai hukum yang tumbuh di masyarakat, eksistensi hukum pidana Islam mampu menggantikan atau mengisi Kitab Undang-undang Hukum Pidana -selanjutnya disingkat KUHP-- yang dipandang sudah tidak relevan lagi dengan semangat zaman (Jaspan 1988, 250).

Kendati demikian, keberadaan hukum pidana Islam --utamanya entitas hukum hudūd-- hingga detik ini belum banyak memberikan kontribusi bagi pembangunan hukum pidana Nasional terutama KUHP yang saat ini masih berlaku. Hal ini terlihat dari muatan materi-materi hukum pidana Islam yang masih "melangit" dan belum terserap dalam KUHP. 
Harus diakui bahwa hukum Islam mempunyai kedudukan lebih strategis karena wataknya yang menekankan moralitas agama berupa adanya pertanggungjawaban di hadapan Tuhan. Hal ini secara empiris sejatinya telah menjadi komitmen para hakim (juris) dalam memutuskan perkara yang selalu mendasarkan kepada Tuhan YME. Dilihat dari akar sejarah, sebagai sumber hukum, hukum Islam sangat mungkin dimasukkan di dalam peraturan undangundang (Ka’bah 1999, 59).

Ketika melihat peranan dan kontribusi hukum Islam terhadap pembangunan hukum nasional, menurut Juhaya S. Praja terdapat beberapa model dan bentuk yang dapat ditemukan dalam praktik. Pertama, hukum Islam berperan dalam mengisi kekosongan hukum dalam hukum positif. Dalam hal ini hukum Islam diberlakukan oleh negara sebagai hukum positif bagi umat Islam. Untuk tipe jenis ini sebagaimana undang-undang tersebut di atas. Kedua, hukum Islam berperan sebagai sumber nilai yang memberikan kontribusi terhadap aturan hukum yang dibuat. Oleh karena aturan hukum tersebut bersifat umum, tidak memandang perbedaan agama, maka nilai-nilai hukum Islam dapat berlaku pula bagi seluruh warga negara (Praja 2011, 260).

Kendati didukung oleh sejumlah argumen yuridis-logis dan kuat, upaya untuk melakukan pembaruan KUHP, melalui bahan baku (sub-sistem) Hukum Pidana Islam ini, tentunya upaya ini tidaklah semudah yang dibayangkan. Realitas sejarah panjang telah menunjukkan bahwa upaya ini berjalan "terseok-seok" sarat dengan kepentingan dan konflik ideologi. Upaya penyusunan RUU-KUHP dengan menjadikan hukum pidana Islam, yang telah dirintis sejak tahun 1963 hingga sekarang ini tak kunjung diresmikan oleh presiden untuk menggantikan KUHP (Reksodiputro 1995, 13).

Singkat kata, dapat dikatakan bahwa upaya positivisasi (transformasi) Hukum Pidana Islam hingga detik kini masih menuai badai pro dan kontra di antara kalangan ahli. Motivasi di balik tuntutan formalisasi pidana Islam beragam. Ada yang karena alasan praktis yaitu sebagai obat bagi degradasi moral di masyarakat yang tidak teratasi oleh hukum pidana saat ini (Soeharno 2012, 6-7). Namun juga banyak yang menolak untuk mempositifkan hukum pidana Islam dengan berbagai macam argumentasi.

Berangkat dari permasalahan tersebut, maka dapat diajukan beberapa pertanyaan yang akan dijawab dalam paper ini: terdapat beberapa pertanyaan 
penelitian sebagai berikut: bagaimana potret dan peta perdebatan teori (epistemologis) di kalangan ahli tentang Hukum Pidana Islam di Indonesia? Bagaimana konstruksi Hukum Pidana Islam antara yang konstan dan profan? Dan bagaimana pelaksanaan Hukum Pidana Islam di Indonesia dalam bingkai hukum nasional? Pertanyaan-pertanyaan tersebut akan dielaborasi dan dijawab dalam paperini.

\section{Materi Hukum Pidana}

Rumusan material Hukum Pidana Islam sejatinya telah digariskan melalui kedua sumber primer Islam yaitu Alqur'an dan Sunnah. Paling tidak, terdapat sekitar 30 (tiga puluh ) nash Alqur'an yang secara eksplisit berkaitan langsung dengan masalah hukum pidana (Khan 1983, 27). Ayat-ayat ini membahas jenisjenis kejahatan, pidana spesifik terhadapnya, dan beberapa aturan pembuktian agar pidana bisa dilaksanakan serta aspek sanksi dan bentuk pidananya. Selain itu, di dalam ayat-ayat juga mengurai tujuan dan prinsip-prinsip dasar dalam penjatuhan sanski pidana juga hakikat dari pelarangan (jarīmah) hudūd dalam hukum Islam. Berdasarkan ayat tersebut, para ahli kemudian membagi jenis-jenis kejahatan di dalam hukum pidana Islam sebagaimana dikaji dalam literatur-literatur yang ada dibagi menjadi tiga: jarîmat al-hudūd, jarīmat qishāsh wa diyat dan terakhir yaitu jarìmat al-ta'zir. Sedangkan sanksi terhadap ketiga jenis kejahatan tersebut dinamakan: 'uqūbah (hukuman) yang masing-masing disebut 'uqūbah al-hudūd (pidana hadd), 'uqubah al-qishāsh wa al-diyat (pidana qisas dan diyat) dan 'uqūbah al-ta'zīr (pidana takzir) (Zahrah 1998, 89).

Qishash adalah hukuman yang sama dan seimbang dengan kejahatan yang diperbuat oleh pelaku tindak pidana (Zahrah 1998, 663). Sedangkan diyat adalah sejumlah harta tertentu yang harus diberikan pelaku kejahatan terhadap jiwa atau tubuh kepada pihak korban sebagai hukuman. Materi hukum qishāsh mencakup dua ranah, yaitu ranah pembunuhan dan ranah pelukaan (melukai badan). Pembunuhan adalah segala perbuatan yang dilakukan oleh seseorang atau kelompok yang mengakibatkan kematian seseorang. Pelaku pembunuhan diancam dengan hukuman mati dan pelukaan pun sama, mencungkil mata dibalas mencungkil mata (Ruysd n.d., 127).

Materi cakupan dari hukum hudūd yaitu: pidana pencurian, pidana perzinaan, pidana menuduh orang berbuat zina (al-qadzaf), mengonsumsi barang yang 
memabukkan (khamr), membunuh atau melukai, mencuri, merusak harta orang lain, jarimah (melakukan kekacauan dan semacamnya berkaitan dengan hukum kepidanaan) (Praja 2011, 233). Materi lainnya adalah pidana qishāsh-diyat, yang merupakan pidana untuk perbuatan pembunuhan atau melukai seseorang dan semua pelanggaran pidana yang lainnya di luar dua katageori tergolong dalam pidana ta'zìr. Walaupun mayoritas ulama sepakat dengan pembagian seperti ini namun tidak berarti tidak ada 'ulama-'ulama minoritas yang berpendapat lain. Perbedaan ini tampaknya terfokus pada jenis perbuatan apa yang masuk dalam kategori pidana hudūd, apakah lebih dari enam perbuatan sebagaimana yang disebutkan di atas atau kurang dari enam, sebagai akibat dari pemahaman mereka yang berbeda-beda terhadap sumber tekstual ayat-ayat Alqur'an maupun hadis tersebut (El-Awa 1982,2-3).

Secara detail juga Alqur'an telah menyebutkan mengenai pidana hadd yang ditegaskan dalam lima ayat, yaitu: QS. 4:15, QS. 5:33, 5:38, QS. 24:2 dan QS. 24:4. Di dalam QS. 5:33 diterangkan mengenai 4 (empat) jenis pidana, di dalam QS. 5:38 ada 1 (satu) jenis pidana, QS. 24:2 ada 1 (satu) jenis pidana, di dalam QS. 24:4 dijelaskan mengenai jenis pidana yang sama dengan dalam QS. 24:2. Dan kemudian di dalam QS. 4:15 disebut mengenai penjara seumur hidup. Selebihnya dijelaskan oleh hadits-hadits Nabi. Dengan demikian, secara rinci dan jelas dalam Alqur'an hanya diterangkan mengenai 7 (tujuh) bentuk pemidanaan ('uqubah) dalam hudūd, yaitu: pidana salib, yaitu untuk tindak pidana hirābah (QS. 5:33); pidana mati, (QS. 5:33); pidana potong tangan dan kaki secara bertimbal balik (QS. 5:33); pidana buang (QS. 5:33); pidana penjara seumur hidup (QS. 4:15); pidana potong tangan untuk tindak pidana pencurian (QS. 5:38); dan pidana cambuk (dera), yaitu untuk tindak pidana perzinaan dan tuduhan palsu (QS. 24: 2 dan 4) (Asshiddiqy 1996, 45).

Berdasarkan pada kajian tematik ayat (nash) tentang pemidanaan tersebut kemudian para ahli merumuskan bentuk-bentuk pidana (al-uqūbāt) yang diterapkan bagi pelaku pidana dikategorikan dalam dua bentuk yaitu: hudūd dan ta'zīr. Hudūd adalah segala bentuk pidana yang jenis pidananya telah dirumuskan oleh Alqur'an dan Sunnah. Sedangkan pidana ta'zīr adalah bentuk pidana yang tidak ditentukan bentuknya oleh Alqur'an dan Sunnah. Dalam kasus qishāsh dan diyat, para ulama berbeda pendapat. Ada yang memandang qishāsh dan diyat masuk dalam kategori hudūd. Namun mayoritas ulama berpandangan keduanya 
tidak termasuk hudūd (Djazuli 2000, 10-14). Qishāsh terkait dengan pembunuhan dan pencederaan anggota badan yang pelakunya diancam dengan tindakan yang sama (Beik 1988, 18-22). Sementara diyat adalah ganti rugi (denda) bagi pelaku tindak pidana ketika qishāsh tidak jadi dilaksanakan karena pemaafan (al-'afwu) dan bagi pembunuh semi sengaja dan tidak sengaja. Sedangkan hudūd adalah haqqullāh (hak Allah) yang pidananya telah pasti ketentuannya dan ada satu bentuk pidana lagi selain hudūd dan ta'zīr yakni kifārat

Sedangkan hukum ta'zīr -yang secara bahasa berarti mencegah kejahatanadalah hukuman yang berupa memberi pelajaran. Pendidikan ini disebut dengan ta'zir karena hukuman tersebut sejatinya dapat menghalangi si-terhukum untuk tidak kembali kepada jarimah atau dengan kata lain membuat efek jera. Para ahli memaknai ta'zir dengan hukuman yang tidak ditentukan oleh Alqur'an maupun Sunnah yang berkaitan dengan kejahatan yang melanggar hak Allah dan hak hamba yang berfungsi agar terhukum tidak mengulangi perbuatannya (Djazuli 2000, 159-63).

Pada kategori materi hukum pidana Islam tersebut, para ahli nyaris sepakat bahwa tindak pidana hudūd merupakan jenis tindak pidana yang telah diatur secara terinci dan bersifat tetap sehingga tidak memungkinkan adanya interpretasi dan perubahan. Semua aturan yang telah digariskan oleh nash harus diterapkan apa adanya dalam realitas sosial. Karenanya tidak ada wilayah ijtihad untuk memahami ulang terkait rumusan tersebut. Argumentasi yang sering dibangun ahli adalah dalam pidana hudūd terdapat hak-hak Allah yang tidak boleh dilanggar oleh siapapun. Walhasil hudūd merupakan korpus tertutup untuk "tangan-tangan" ijtihad untuk melakukan reaktualisasi apalagi rekonstruksi.

Formulasi Hukum pidana aspek hudūd yang demikian dewasa ini banyak digugat oleh para teoritisi Muslim modern. Abdullahi Ahmed al-Na'im misalnya, memandang bahwa hukum publik Islam terutama aspek hudūd, qishāsh dan yang sejenisnya, hanya bisa dijadikan landasan dan konsisten dengan konteks historisnya. Namun, menurutnya, tidak dapat dijadikan alasan dan (tidak secara) konsisten bersesuaian dengan konteks kekinian (An-Na'im 1996, 34). Demikian halnya dengan Ibrahim Hosen, ahli hukum Islam dari Indonesia, berpendapat perlu pendekatan ta'aqquli dalam memahami ketentuan pidana (jarimah) hudūd dalam hukum pidana Islam. Dengan pendekatan ini maka hukum Islam dapat 
dikembangkan melalui pendekatan qiyās, maqāshid al-syari’ah dan hikmat al-tasyrī' (Hossen 1990, 126-28).

Kontruksi Hukum Pidana Islam utamanya aspek pidana hudūd yang dirumuskan oleh para ahli yang termaktub dan tersebar dalam kitab-kitab fiqh klasik, dewasa ini banyak menuai kritikan dari kalangan ahli kontemporer (Rosyidi and Ahmad 2006, 34-37). Namun, dalam hemat penulis, persoalan yang paling mendasar bukan pada kritik dan perbedaan tajam antara fuqaha' tersebut. Melainkan justru pada tarik-menarik dan ketegangan seringkali muncul pada saat Hukum Pidana Islam (HPI) --utamanya pidana (jarīmah) hudūd-- hendak diimplementasikan atau akan diformalkan (positivisasi) ke dalam produk perundang-undangan yang berada di bawah konstitusi Negara (baca: Indonesia). Secara faktual, pidana hudūd berada di antara paradigma agama dan paradigma negara. Indonesia merupakan negara yang tidak menjadikan Islam sebagai agama resmi negara. Demikian halnya tidak pula menjadikan syariat (hukum) sebagai satu-satunya sumber dalam pembuatan hukum nasional, namun mengakui syari'at (hukum) Islam sebagai hukum yang hidup di masyarakat (living law).

\section{Hukum Pidana Islam (HPI) dalam Perdebatan Epistemologis}

Apabila diajukan pertanyaan mengapa Hukum Pidana Islam belum mampu bertransformasi menjadi Hukum Pidana Nasional? Tentunya akan muncul banyak variabel untuk menjawabnya. Artinya, akan banyak lahir jawaban yang bervarian perspektifnya. Sa'id Agil Husin al-Munawar misalnya, paling tidak ada tiga problem dan kendala terkait upaya transformasi hukum pidana Islam (HPI) menjadi hukum pidana Nasinal dihadapkan dengan sejumlah kendala seperti pluralisme bangsa, metode pendidikan hukum yang bersifat dan cenderung trikotomis serta minimnya pengkajian akademik di bidang hukum Islam (AlMunawar 2004, 17). Sementara menurut A. Djazuli, kesulitan transformasi Hukum Pidana Islam ke dalam hukum pidana nasional disebabkan karena adanya prinsip unifikasi (Coulson 1987, 59) dalam hukum pidana itu sendiri (Djazuli 2000,34-39).

Transformasi hukum pidana Islam (HPI) dalam hukum pidana nasional berhadapan dengan sejumlah kendala, baik ektsernal maupun internal. Kendala eksternal seperti: historisitas, kendala sosial-budaya, kendala institusional. Secara internal disebabkan Hukum pidana Islam (HPI) yang dikaji dalam kitab-kitab fikih 
klasik sarat dengan perbedaan tajam antara beberapa ahli. Thahir Azhari juga mengajukan argumen bahwa formalisasi hukum pidana Islam dalam beberapa perspektif tata hukum Indonesia ternyata sangat dirasa rumit. Sebab berkaitan dengan pelbagai aspek historis, ideologis, politis, yuridis, religius, sosiologis, dan kultural, baik dilingkup nasional maupun internasional. Singkat kata, melalui formalisasi dan legislasi, hukum Islam telah bergeser dari otoritas hukum agama (devine-law) menjadi otoritas hukum negara (state-law) (Azhari 1992, 43).

Selain itu, menurut Abdullah Gani, menurut asas legalitas, hukum pidana Islam dikategorikan sebagai hukum tidak tertulis. Ketiadaan hukum pidana Islam (HPI) secara tertulis di Indonesia menjadi penyebab belum dapat terpenuhinya hukum pidana Islam (HPI) secara legal. Dengan demikian, HPI harus benar-benar disiapkan secara tertulis sebagaimana hukum positif lainnya, bukan langsung merujuk pada sumber hukum Islam, yakni Alquran, Sunnah, dan ijtihad pada ulama (kitab-kitab fiqh) (A. G. Abdullah 2011, 246). Topo Santoso juga menambahkan bahwa ketiadaan konsep yang matang tentang hukum pidana Islam dan kurang melembaganya prinsip hukum pidana Islam menjadi kendala bagi formalisasi hukum Islam. Kenyataan ini berbeda dengan hukum perdata yang sudah membaur dan menyatu dalam kehidupan masyarakat, sehingga masyarakat merasa terlibat langsung. Sedangkan hukum Islam di bidang kepidanaan ini belum mendapatkan tempat (Santoso 2010, 105).

Persoalan menjadi semakin kompleks ketika hukum pidana Islam (HPI) juga sering mendapat stigmatisasi sebagai hukum yang out of date dan dehumanis. Sebagian Orientalis melihat hukum Pidana Islam (HPI) sebagai sosok hukum yang kejam, primitif dan menerapkan konsepsi balas dendam (Santilana 1952, 151). Sementara Joseph Scahcht menyatakan bahwa hukum pidana Islam menunjukan adanya dua unsur yang ditempatkan secara berdampingan tanpa menjadikannya satu, yakni ide-ide Arab kuno yang dimodifikasi Alqur'an serta gagasan murni tentang kejahatan dari Alqur'an (Schacht 1955, 153). Singkat kata, dapat dikatakan bahwa sejumlah kendala dan stigmatisasi terhadap hukum pidana Islam tampaknya telah menjadi hambatan dan kendala dalam upaya transformasi di Indonesia.

Berkenaan dengan cita-cita pemberlakuan dan penegakan hukum pidana Islam (HPI) dalam konteks formalisasinya di Indonesia, Masykuri Abdillah mengemukakan elaborasi menarik (Abdillah 1999, 7). Menurutnya, sejak era 
reformasi, muncul aspirasi umat Islam yang variatif, baik dari aliran ekslusif yang fundamentalistik sampai yang inklusif yang cenderung liberalistik. Paling tidak terdapat tiga pandangan seputar hukum pidana Nasional vis a vis hukum pidana Islam. Pertama, bahwa hukum pidana Nasional (positif) itu kompatibel dengan hukum pidana Islam, seperti tentang pelanggaran. Kedua, hukum pidana positif itu tidak bertentangan dengan hukum Islam, tetapi juga tidak sepenuhnya sama dengan hukum Islam, seperti tentang pencurian, pembunuhan, dan sebagainya. Ketiga, hukum pidana positif bertentangan dengan hukum (pidana) Islam, seperti hukum perzinaan dan minuman keras yang pelakunya hanya dapat dipidana jika merugikan pihak lain.

Berdasarkan elaborasi problematika di atas, dalam hemat penulis, akar utama penyebab kesulitan menjadikan hukum pidana Islam adalah adanya pertentangan epistemologis yang sangat tajam antara ilmu hukum Pidana Islam pada satu sisi dan epistemologi hukum nasional pada sisi lain. Artinya, secara internal, umat Islam masih telah terdiametral dalam dua kutub pandangan yang berbeda berseberangan. Utamanya aspek bentuk-bentuk pemidanaan kategori hudūd dalam hukum pidana Islam (Nurrohman 2012, 259-75). Pada satu sisi memandang bahwa aplikasi pidana hudūd sebagai hukum Allah bersifat final mengikat karena ia bersifat qath'ì al-dilalah (bermakna pasti dan final). Sementara teoritisi hukum pidana Islam lainnya menilai bentuk-bentuk pidana (al-uqūbah) yang termaktub dalam Alqur'an al-Sunnah hanyalah bersifat instrumental bukan tujuan utama (Nurrohman 2019).

Terkait perdebatan epistemologis ini, Juhaya S. Praja berpandangan bahwa dalam konteks keindonesiaan, pemikiran hukum Islam sepertinya dihadapkan pada dua kelompok: sebagian menyuarakan anti perubahan (pembaruan) hukum Islam dan sebagian menyuarakan perlunya perubahan (pembaruan). Dalam kerangka kelompok pertama, perubahan substansial yang meliputi esensi materi hukum tidak akan terjadi. Ketergantungan pada teks fiqh klasik yang begitu kuat, dan sempitnya peluang untuk menciptakan syarah interpretatif ketimbang syarah normatif, serta minimnya respons sosial-religius terhadap kasus-kasus hukum yang banyak bermunculan. Ini semua membuktikan ketidakberdayaan hukum Islam. sedangkan dalam kerangka kelompok kedua, perubahan (pembaruan) hukum dimungkinkan seiring dengan perubahan zaman, tempat dan kondisi adat-istiadat (Praja 2011,ix). 
Menelisik lebih jauh, melalui kajian hukum pidana Islam, diketahui bahwa fuqahä' hampir semuanya sepakat bahwa ketentuan hudūd (Ukaz 1982, 67-68) merupakan wilayah yang bersifat qath'ī al-dilālah (Al-Jashshash 1993, 5-6). Artinya, ketentuan bentuk-bentuk pidana seperti pidana rajam, potong tangan, cambuk (dera) dan lain sebagainya yang terkandung dalam pidana hudūd mempunyai makna pasti dan bersifat final (fixed punishment). Walhasil tidak ada tafsir lain atas bentuk-bentuk pidana ('uqūbah) di dalamnya. Tidak mengherankan jika dalam kitab-kitab karya 'ulamā'/fuqahā', kajian-kajian hudūd dalam hukum pidana Islam cenderung stagnan, sebab hudūd merupakan korpus yang tertutup bagi aktivitas ijtihad (Al-Syaukani 2009, 250).

Abi al-Hasan al-Husaini al-Jurjani misalnya, dalam karyanya al-Ta'rifāt, mendefinisikan hudūd dengan istilah: sanksi yang telah ditentukan dan wajib dilaksanankan secara haq karena Allah SWT (Al-Jurjani 1938, 88). Senada dengan pemaknaan di atas, 'Abd al-Qadir 'Audah, dalam karyanya al-Tasyrì' al-Jināīi alIslāmī, memaknai hudūd dengan istilah sanksi yang ditentukan secara syara' ('Audah 1996, 343). Demikian halnya dengan al-Sayyid Sabiq, ahli fiqh dari Mesir, mengemukakan bahwa hudūd secara bahasa berarti pencegahan. Sanksi-sanksi kemaksiatan disebut dengan hudūd, sebab secara umum dapat mencegah pelaku dari pengulangan tindak pidana (Sabiq 1997,302).

Lebih lanjut, dalam karyanya al-Ahkām al-Sulthāniyyah, al-Mawardi memberikan jawaban argumentatif, mengapa ketentuan hudūd bersifat pasti dan tidak bisa berubah kadar pidananya? Karena di dalam ketentuan-ketentuan hudūd terdapat hak Allah (haqqullăh) yang tidak dapat digugurkan. Lebih dari itu, di dalam ketentuan bentuk (pidana) hudūd terkandung kemaslahatan umum (masyarakat) bukan kemaslahatan personal (individu) (Al-Mawardi n.d., 22173).

Rumusan senada telah dikemukakan ahli 'Abd al-Qādir 'Audah. Menurutnya, hakikat pidana hudūd adalah bentuk sanksi pidana (al-'uqūbāt) yang ketentuannya dan sanksinya telah ditetapkan Allah dan pemidanaan yang di dalamnya telah ditetapkan kemaslahatan kolektif dan mengandung hak Allah SWT. Dengan demikian, maka pidana hudūd tidak dapat digugurkan oleh perorangan maupun kelompok. Bahkan seorang hakim pun tidak boleh mengurangi dan menambahi terkait pidana hudūd ('Audah 1996, 634-35). Hak Allah adalah bentuk pidana yang berkaitan erat dengan kepentingan masyarakat (delik umum) sedangkan hak 
manusia (haqq al-Ādami) adalah pidana yang berkaitan dengan kepentingan hak individu yang bersifat personal (delik aduan). Sebagai delik aduan, maka pidananya dapat digugurkan oleh korban atau penguasa (baca: hakim) karena hanya menyangkut kemaslahatan pribadi (Bahansi 1961,56).

Bagi mereka yang setuju dengan formalisasi pidana (jarimah) hudūd pada umumnya mengajukan berbagai alasan antara lain: pertama, bahwa mayoritas rakyat Indonesia beragama Islam oleh karenanya wajar bila hukum yang berlaku di Indonesia, khususnya bagi umat Islam adalah hukum atau syariat Islam. Kedua, bahwa adanya jaminan konstitusional bagi diberlakukannya syariat Islam bagi pemeluknya sebagai tercermin dalam Piagam Jakarta merupakan suatu perjanjian luhur yang telah disepakati oleh para pendiri republik ini sebagai jalan kompromi dari dua pilihan yakni negara sekuler dan negara Islam (agama). Ketiga, bahwa berlakunya syariat Islam tidak akan merugikan pihak lain diluar Islam, karena syari'at Islam akan membawa rahmat bagi umat manusia (Nurrohman 2019, 5-6).

Sementara bagi tidak sepakat mengajukan alasan antara lain: Pertama, pencantuman tujuh kata dalam Piagam Jakarta akan membuka kemungkinan campur tangan negara dalam wilayah agama yang akan mengakibatkan kemudlaratan baik bagi agama itu sendiri maupun bagi negara sebagai wilayah publik. Kedua, dimasukannya frase tersebut akan mengakibatkan munculnya prasangka-prasangka lama kalangan luar Islam mengenai negara Islam di Indonesia. Ketiga dimasukkannya kembali frase tersebut bertentangan dengan sistem negara nasional yang memperlakukan semua kelompok, termasuk kelompok agama di negeri ini secara sederajat (Nurrohman 2019).

Pasca tumbangnya Orde Baru yang disusul dengan Era Reformasi, mencuat kembali tuntutan sebagian kelompok Islam untuk memformalkan syari'at Islam khususnya pidana Islam. Namun di sisi lain, ada kekhawatiran dari kelompok Islam yang lain, karena banyaknya ketentuan-ketentuan dalam pidana Islam yang dianggap tidak sejalan dengan demokrasi. Perbedaan di atas, memang dapat dimaklumi, sebab dilihat dari orientasi keberagamaan masyarakat Indonesia dapat dilihat dari beberapa aspek: Pertama, kelompok yang menjadikan Islam sebagai ideologi yang manifestasinya berbentuk penerapan hukum Islam. Kedua, kelompok yang hanya berorientasi dari moral etik beragama, tanpa harus ada formalisasi hukum Islam. Alasan dari kelompok ini, formalisasi hukum Islam sesungguhnya merupakan langkah mundur dalam berdemokrasi. Menurutnya, 
formalisasi syari'at Islam kurang strategis dan efektif. Dalam konteks negara yang berdasar pancasila, meskipun undang-undang otonomi daerah telah diberlakukan, namun tidak berarti setiap daerah berhak menetapkan politik hukum sendiri berdasar atas kecenderungan dominasi satu kelompok atau etnis tertentu (M. Wahid 2002, vi-vii).

Upaya formalisasi pidana Islam di Indonesia telah termanifestasikan dengan representasi Provinsi Nangroe Aceh Darussalam (NAD). Terbitnya Qānūn Syariah di Aceh pada tahun 2003 merupakan langkah revolusioner. Dalam Qānūn ini aspek hukum pidana Islam yang tercakup dalam hudūd telah berhasil diimplementasikan. Pidana dera (cambuk) bagi pemabuk, penjudi dan pezina diberlakukan dalam provinsi ini. Khusus untuk Provinsi Nanggroe Aceh Darussalam, pemberlakuan Qanun Provinsi NAD Nomor 10/2002 dan Qanun Provinsi NAD Nomor 11/2002 Nomor 12/2003 Nomor 13/2003 menjadikan hukum pidana Islam dan metode eksekusinya berupa cambuk sudah diterapkan di wilayah Indonesia.

Kendati Qanun Aceh dan perda-perda berbasis syariah telah banyak diundangkan di beberapa daerah di tanah air dan dihasilkan melalui mekanisme yang benar, namun keberadaan perda-perda tersebut juga telah menuai pelbagai kritik tajam dari kalangan. Mahsun Faiz misalnya, mengkritik bahwa eksperimentasi di Aceh belum menunjukkan kemajuan terhadap pemaknaan syariat itu sendiri. Sebab, formalisasi di Aceh hanya tidak lebih dari merevitalisasi atau (mengadopsi) nilai-nilai ke-Islaman yang berkembang di Timur Tengah sebagai jalan untuk menegakkan hukum-hukum Tuhan di muka bumi. Karena faktanya, penerapan pidana dera hanya menyentuh kaum lemah, dan belum mampu menyentuh kejahatan ekonomi, sosial dan politik semisal pelaku tindak kejahatan korupsi (Maksun 2005, 151-54).

Kritik senada juga dilontarkan Aguswandi menyatakan bahwa penerapan syariat Islam yang konservatif di Aceh mesti jadi pelajaran bagi setiap orang. Mestinya umat Muslim tidak mengulangi kegagalan dan membiarkan kelompok konservatif mendikte syari'at Islam seperti yang terjadi di Aceh. Banyak yang tidak menyadari betapa Islam di Aceh telah dieksploitasi sedemikian rupa oleh kelompok konservatif untuk mempromosikan sesuatu yang baru yakni tipe Islam yang menindas wanita, membatasi kebebasan berbicara, menerapkan aturan 
tingkah laku yang ketat yang sebenarnya bertentangan dengan tradisi lokal dan watak Islam itu sendiri.

Selain itu, barisan yang tidak setuju diformalkannya hukum pidana Islam melalui undang-undang Negara. Sebab, dengan diformalkan hukum pidana Islam melalui undang-undang Negara, menjadikan penerapan pidana Islam menjadi tergantung pada Negara. Sementara bagi para pendukung diformalkannya hukum pidana Islam, akan menjadikan hukum pidana Islam mempunyai daya ikat dari luar dan akan lebih efektif karena mempunyai daya paksa dari struktural. Bahkan adanya anggapan bahwa hukum Islam paling tidak sebagian darinya tidak bisa dilaksanakan tanpa adanya kekuasaan politik setingkat Negara karena hukum Islam menurut mereka tidak hanya mengatur urusan privat tapi juga urusan publik. Oleh karena itu keberadaan Negara bagi umat Islam merupakan kemestian sesuai dengan kaidah yang berbunyi: "mā lā yatimmu al-wājib illā bihi fahuwa wājib" (Zahrah 1997, 239-43) (segala entitas yang kesempurnaannya sangat tergantung padanya, maka entitas tersebut menjadi niscaya).

Paparan sekaligus hipotesis yang dikemukakan di atas sejatinya telah menyuguhkan problematika faktual akan adanya konflik dan ketegangan diametral dalam bidang episteme (nalar) di kalangan ahli terkait pro-kontra penerapan pidana-pidana hudūd dalam hukum pidana Islam (HPI) (Mahendra 1999, 23738). Singkatnya, dalam konteks upaya transformasi hukum pidana Islam (HPI), terutama aspek pidana hudūd, di Indonesia masih terkendala oleh dua pendekatan (teori) yang seakan-akan harus berhadap-hadapan untuk memperjuangkan kebenarannya masing-masing. Pendekatan tersebut adalah teori jawābir yang banyak diusung oleh kaum fundamentalisme Islam dan teori zawājir yang banyak diusung oleh kaum modernisme. Keduanya hingga kini cenderung sulit dicarikan "titik temu" yang berujung pada terkatung-katungnya harmonisasi atau transformasinya hukum pidana Islam (al-fiqh al-jinā’î) ke dalam hukum pidana Nasional (Mahendra 1999, 240-41).

Berdasarkan pada elaborasi medan perdebatan yang tersaji di atas, dapat dipahami bahwa alotnya transformasi HPI menjadi hukum nasional karena terjadinya pertentangan dan perdebatan nalar Hukum Pidana Islam sebagai entitas yang bersifat subjektivisme-teistik (konstan)' dengan sesuatu yang bersifat objektivisme-rasionalistik, (profan). Dalam bahasab lain antara HPI sebagai divine- 
law dengan hukum produk manusia (man-made law). Atau dengan bahasal yang lugas antara hukum dengab pendekatan revelation (wahyu) dengan reason (akal).

\section{Reformulasi Teori 'Uqubah; Menemukan Entitas Profan}

Memperdebatkan Hukum Pidana Islam sebagai produk wahyu atau akal, sebagai hukum Tuhan atau hukum manusia, sebagai hukum sakral atau tidak, entitas yang konstan atau profan, dalam hemat penulis, bukanlah langkah yang arif dan bijak. Sebab, secara faktual hakikat Hukum Pidana Islam sejatinya merupakan produk (penalaran) perpaduan antara produk Tuhan (wahyu) dan produk akal manusia (fiqh).

Hukum Pidana Islam tidaklah datang pada ruang kosong yang hampa. Melainkan turun pada saat masyarakat Arab pra-Islam telah mengenal pranata yang berlaku. Pun dengan bentuk-bentuk hukuman dalam hukum pidana Islam, sejatinya telah berkembang, berlaku dan dipraktikkan masyarakat Islam pra-Islam. Khalil Abdul Karim, menyatakan bahwa banyak hal yang terkait dengan pranata sosial lokal Arab pra-Islam yang telah diadopsi dan diakomodir untuk kemudian dijadikan sebagai bagian dari doktrin keagamaan Islam (Karim 2002).

Dalam kondisi demikian, Nabi justru melakukan akulturasi dan inkulturasi dengan budaya setempat yang lebih memungkinkan adanya penerimaan masyarakat secara inklusif terhadap Islam (Abu Hapsin 2019). Kebanyakan hukum-hukum yang menyangkut perdata dan pidana, seperti biasa ditemukan dalam berbagai kitab fiqh, merupakan keberlanjutan dari hukum-hukum yang telah ada sebelum Islam. Di antara pranata sosial tersebut ada yang diterima secara total, ada yang diterima dengan modifikasi dan ada yang ditolak. Namun khusus untuk bidang mu'amalah dan pranata sosial kebanyakan diterima dan kemudian diintegrasikan menjadi bagian dari Islam (Mu'izzuddin 2019). Inilah realitas historis terkait pergumulan hukum pidana Islam dengan tradisi dan pranata sosial Arab pra-Islam yang tak terbantahkan.

Islam mengakui beberapa dari hukum adat dan pranata sosial masyarakat Arab pra-Islam dan menghapus sebagian lagi. Mereka menghindari perkawinan dengan ibu-ibu serta anak-anak, dan, hal ini "diamini” oleh Islam. Sementara mengawini janda-janda dari ayah mereka dipandang sebagai perbuatan yang sulit dipercayai, karena itu, Islam melarang praktik demikian. Demikian halnya praktik hukum potong tangan karena seorang pencuri juga mendapat dukungan dalam Islam. 
Dalam bidang mu'amalah, perkongsian yang menjadi kebiasaan orang Arab pada akhirnya juga menjadi hukum yang diadopsi oleh Islam (Paydar 2003, 133).

Berdasarkan kenyataan historis inilah, maka banyak para ahli sejarah hukum Islam yang mengatakan bahwa aturan-aturan hukum yang termuat dalam Alqur'an secara materiil banyak yang terserap dari realitas masyarakat Arab pra-Islam yang sudah ada. Jadi, ketentuan hukum pidana Islam tidak bisa dilepaskan dari setting sosial yang melatarbelakanginya.

Selain itu, pengaruh peradaban dua adidaya yang mengapit jazirah Arab, yaitu Byzantium dan Persia, telah merembet ke dalam bidang hukum pidana. Pada umumnya, praktik pemberian hukuman sebelum Islam bersifat sangat keras dan berorientasi kepada pembalasan terhadap setiap tingkah laku yang dianggap menyimpang. Bahkan, sebagian tradisi hukum pra-Islam lebih mencerminkan kepentingan elit daripada rakyat banyak. Ketimpangan demikian juga terjadi dalam praktik hukum Yahudi yang dianggap religius. Ini karena dalam masyarakat telah tumbuh segmen aristokrat dan borjuis (Asshiddiqy 1996, 53-54).

Sebagaimana dalam Islam, dalam agama Yahudi, hubungan seksual antara orang-orang yang tidak terikat perkawinan yang legal juga sangat dilarang. Di dalam Deut. 17: 16 ditentukan: "At the mouth of two witnesses, or three witnesses, shall he that is ti die,be put to death; at the mouth of one witness he shall not be put to death.”. Artinya, dengan dua atau tiga orang saksi, sudah cukup bagi pihak penguasa untuk menjatuhkan sanksi pidana kepada para pelaku perzinaan (Asshiddiqy 1996, 57). Ini diubah oleh Alqur'an dengan keharusan membuktikan perbuatan pidana tersebut dengan empat orang saksi. Jika bukti tersebut tidak dapat dipenuhi, si penuduh dianggap sudah membuat tuduhan palsu dan untuk ia diancam dengan pidana 80 kali cambukan.

Hukuman rajam juga dikenal dan telah dipraktikkan pemeluk Nasrani. Dalam Injil Ulangan 22 dikemukakan tentang keperawanan isteri misalnya, diatur dalam Injil Ulangan 22 Perjanjian Lama (Old Testament), mulai dari ayat 13 sampai 21. Jika pihak keluarga isteri dapat membuktikan bahwa anak perempuannya dalam keadaan perawan ketika dikawini laki-laki yang menuduhnya tidak perawan lagi, maka laki-laki tersebut dihukum dengan dipukuli (ayat 17-18). Jika tuduhan lakilaki itu benar, maka perempuan itu dihukum dengan dilempari batu sampai mati (ayat 20-21). Hukuman rajam dikemukakan pada ayat 23-24: Ketentuan rajam berbeda dengan agama Nasrani, dalam Perjanjian Baru, Kitab Johannes 8 (3-11) 
disebutkan tentang hukuman rajam dengan batu, tetapi Yesus tidak ma menerapkannya. Bahkan, Yesus membiarkan pelakunya pergi. Hal yang menarik dari Perjanjian Lama adalah bahwa rajam dikenakan pada pelaku yang "ghairu muhshān" (Ulangan 22: 23-24) sedangkan pada pelaku "muhshān" dikenakan hukuman mati (Imamat 20). Memang tidak ada penjelasan bahwa yang dimaksud dengan hukuman mati tersebut juga adalah rajam (Ali 2014,47-48).

Berdasarkan paparan historis di atas, dapat disimpulkan bahwa hukuman rajam dan lainnya sejatinya bukanlah lahir dari Islam. Artinya, hukuman ini sudah dimuat di dalam kitab-kitab ajaran agama samawi sebelum Islam. Islam kemudian mengadopsinya karena hukuman itulah yang telah melembaga saat itu (Ali 2014, 98).

Kendati demikian, ajaran yang dibawa Nabi Muhammad membuat perubahan besar-besaran di bidang hukum, dengan memperkenalkan gagasan ketuhanan, prinsip-prinsip kemanusiaan, dan cita-cita keadilan dan kedamaian baru. Dalam bidang hukum pidana, Islam memperkenalkan gagasan-gagasan penyesuaian dalam ketentuan penerapan pidana qishash-diyat, rajam, perzinaan, tuduhan palsu, dan pembunuhan. Ketentuan-ketentuan ini mengalami banyak perubahan prinsip jika dibandingkan dengan ketentuan pidana sebelum Islam seperti hukum Yahudi, Nasrani, dan beberapa hukum klasik lainnya seperti Mesir Kuno dan Hammurabi (Asshiddiqy 1996, 55).

Jika ditelisik lebih jauh lagi, dalam hal pemberlakuan syariat misalnya, kehadiran Islam, melalui pranata hukum pidananya mengandung tiga prinsip utama yaitu: (1) mengurangi pembebanan (taqlil al-takālif (2) menghilangkan kesulitan ('adam al-haraj) dan (3) gradualisasi dalam hukum (al-tadarruj fi altasyrī) (Beik 1988, 18-22). Kendati demikian, stigma terkait hukuman dalam Islam senantiasa muncul pada era modern ini. Dalam hemat penulis, stigma tentang kekerasan hukuman dalam pidana Islam ini lebih dipengaruhi oleh fenomena dominannya bentuk corporal punishment (hukuman badani) di dalamnya. Hampir semua bentuk hukuman untuk perbuatan pidana yang disebutkan dalam sumber teks Islam memang berkisar pada hukuman-hukuman yang bersifat fisik, seperti dipotong tangannya, dicambuk, dilempar dengan batu (dirajam) dan lain-lainnya.

Di sini penulis mengatakan bahwa lahirnya corporal punishment (hukuman badani) yang banyak terumuskan dalam Hukum Pidana Islam, lebih banyak 
dipengaruhi paradigma retribusi dalam pemidanaan. Paradigma ini merupakan paradigma paling klasik (tua) di antara paradigma lainnya. Asumsi dasar dalam teori pemidanaan ini adalah bahwa pemidanaan ini merupakan imbalan negatif sebagai tanggung jawab atas kesalahannya. Paradigma retribusi ini telah melahirkan dua teori pemidanaan seperti: teori pembalasan (revenge theory) dan penderitaan dan penebusan (expiation theory). Teori pembalasan ini tampak dalam ayat-ayat hukuman hudūd yang menggunakan terma jazā’ yang bermakna balasan dalam hukuman sebagai pemidanaan. Oleh karena itu, analisis berikut ini, akan banyak diurai terkait hukuman-hukuman badan ditinjau dari perspektif sejarah-sosial pidana Islam. Hal ini penting dilakukan dalam rangka menemukan makna nilainilai universal dalam ketentuan pidana tersebut.

Terkait hukuman-hukuman dalam pidana Islam, analisis historis-sosiologis kritis juga ditawarkan oleh al-Jabiri khususnya hukuman potong tangan. Ia berpendapat bahwa hukum potong tangan secara historis merupakan praktik masyarakat di semenanjung Arabia. Analisis al-Jabiri berangkat dari fakta historis bahwa dalam kondisi masyarakat Badawi (nomadik), penduduknya berpindahpindah dari satu oase ke oase 'lainnya, dari satu tempat ke tempat lainnya dengan kendaraan mereka yakni unta. Hal ini mereka lakukan dalam rangka mempertahankan hidup mereka juga hewan piaraan (ternak) yang mereka gembalakan. Pada konteks sosial demikian, hukuman badan menjadi solusi yang sangat aplikatif, dibanding dengan hukuman pengasingan atau lainnya. Sebab, bangunan penjara sangat jarang dijumpai. Selain itu, tidak ada kekuasaan yang menjadi instrumen penahanan atau pengasingan para pencuri, untuk memberi makan dan minum terpenjara (Al-Jabiri 2001, 165). Karena itu, hukuman yang diberikan adalah hukum potong tangan. Sedang pada masa Islam, situasinya tidak berubah, sehingga hukum potong tangan tetap berlaku. Atas dasar argumentasi di atas, kemudian al-Jabiri memandang bahwa hukuman bagi pencuri substansinya bukanlah potong tangan, melainkan hukuman yang bisa membuat si pelaku menjadi jera. Ini artinya, hukum potong tangan bisa saja diganti dengan, misalnya, hukuman penjara atau lainnya

Demikian halnya dengan hukuman dera (jilid) bagi pelaku zina, qadzaf dan peminum khamer, dalam sejarahnya, hukuman ini juga telah berlaku pada masyarakat Arab pra-Islam. Mengawali analisis terkait hukuman jilid bagi pezina, al-Jabiri mengawali dengan pertanyaan, mengapa jika pencuri hukumannya 
dipotong tangannya, karena yang mencuri adalah tangannya, namun dalam kasus zina bukan digebiri (potong kemaluan) hukumannya? Sulit untuk menjawab pertanyaan demikian, terlebih dengan pendekatan qiyās (analogi) akan sulit tercapai. Pada titik ini, al-Jabiri ketika memahaminya dengan pembacaan sejarahsosia. Ia lebih memahami hukuman ini yang bersifat badaniah (jilid/dera) karena pada masyarakat nomadik keterbatasan infrastruktur untuk melakukan hukuman lain selain jilid. Pada saat Islam datang, kondisi sosial, budaya dan lainnya pada saat Nabi berdakwah tidak jauh berbeda dengan masa sebelumnya. Tak pelak hukuman-hukuman bersifat fisik: jilid dan dera dipelihara dan dilanjutkan dalam tradisi Islam yang dalam hal tertentu diberi bingkai moral-etis oleh Muhammad.

Untuk memperkuat tesis ini al-Jabiri mengemukakan pandangan terkait konstruksi hukuman dera bagi pezina, adalah syarat-syarat yang telah ditentukan oleh para fuqaha' klasik. Sebab, pada konteks masyarakat yang nomadik, kamar tidak ada, dinding rumah masih jarang, atap bangunan masih sepi, maka syaratsyarat yang ditentukan yakni disaksikan empat orang saksi dengan mata telanjang, dan pelakunya tanpa memakai sehelai pun pakaian, sangat mungkin terjadi dan dibuktikan. Namun, syarat-syarat demikian, bagi al-Jabiri, tidak akan masuk akal dan sulit bahkan mustahil dibuktikan pada kondisi dan peradaban masyarakat modern yang semua infra struktur serba rapat dan penuh dengan dinding bangunan. Dengan demikian, syarat-syarat yang dirumuskan fuqaha' klasik terkait terpenuhinya eksekusi hukuman jilid, akan sulit terwujud (Al-Jabiri 2001, 168). Dengan demikian, ketika kondisi sosial masyarakat berubah, tentunya akan berdampak pula pada perubahan bentuk hukuman dalam tindak pidana zina.

Pada titik analisis ini, penulis meneguhkan bahwa pembacaan yang akurat terhadap tradisi lokal Arab pada saat Alqur'an diturunkan sangat penting dan urgen untuk dilakukan dalam rangka menemukan makna objektif yang terkandung di dalam bentuk hukuman dalam Islam. Dari sini akan dapat diketahui aspek-aspek apa saja dari Alqur'an yang bersifat universal-eternal dan aspek-aspek apa saja yang bersifat lokal-temporal. Metode demikian sangat vital agar pengembangan hukum pidana Islam ke depan tidak terjebak pada pengkultusan tradisi lokal Arab, meskipun tidak harus dirubah kalau memang tidak diperlukan. Selain itu, pemahaman yang mendalam terhadap tradisi lokal Arab akan sangat berguna bagi terciptanya produk hukum Islam yang diwarnai dengan kelenturan-kelenturan doktrinal. Selain itu, pengungkapan nilai-nilai universal dalam hukum pidana Islam 
menjadi penting. Tidak hanya dalam konteks akomodasi terhadap budaya lokal (al-'urf) saja, melainkan juga dalam konteks respons terhadap perkembangan dunia moden, baik bidang politik, ekonomi maupun sosial budaya lainnya (Abdillah 2011, xx-xxi).

Pendek kata, dalam konteks perubahan sosial dan transformasi global, maka umat Islam sejatinya dapat mencari bentuk sanksi-sanksi hukum alternatif yang paling mungkin dan efektif untuk menjerakan para pelaku kejahatan. Hal ini dapat digunakan dengan metode pengasingan (yunfau) yang juga dinyatakan dalam Islam atau yang lainnya (Al-Qurthubi n.d., 79). Sebagian ahli, seperti Muhammad Syahrur, berpandangan bahwa hukum potong tangan dan rajam merupakan hukum maksimal (al-hadd al-a'lā) yang hanya dapat diaplikasikan ketika sanksisanksi hukuman di bawahnya tidak lagi efektif dan relevan untuk mengurangi angka kejahatan.

Analisis terakhir terkait aspek pidana dalam hukuman, maka pemanfaatan teori dan ilmu kontemporer akan meniscayakan multi-pendekatan. Artinya, dalam rangka mengaplikasi Hukum Pidana Islam maka perlu pelibatan ilmu pemidanaan (Penologi) kontemporer. Multi-pendekatan ini merupakan kebutuhan mendesak sekaligus merupakan langkah metodologis dalam rangka mencari relevansi hukuman dalam Islam agar sesuai dengan rasa hukum masyarakat muslim modern tanpa harus meninggalkan nilai-nilai mulia (maqāshid al-syarīah) yang telah ada dan ihnern di dalamnya.

Dewasa ini, penelitian dan kajian terkait kriminologi dan penologi dalam kajian hukum pidana telah mengalami pergeseran-pergeseran paradigma yang begitu cepat. Para kriminolog lebih menekankan akan urgensi dimensi "rasionalitas" dalam perumusan sebuah hukuman yang lain selain dua aspek retribusi dan penjeraan. Artinya, konsentrasi dan fokus para ahli phenology modern sekarang ini tampak lebih menekankan pada sifat perbaikan (reformation) dari penjatuhan sebuah hukuman (El-Awa 1982, 34) Dalam perspektif para ahli pemidanaan, sifat reformasi berarti menekankan arti penting "pengobatan" (cure) dalam pemidanaan. Teori ini tampak berbasis pada sebuah pemikiran bahwa orang yang melakukan kejahatan, tidaklah pantas dikategorikan sebagai "orang yang jelek" akan tetapi "orang yang sedang sakit". Dengan demikian, maka ibarat orang yang sakit, orang yang melakukan kejahatan itu sesjatinya membutuhkan pengobatan dan pertolongan. Selanjutnya el-Awa mengatakan "... some 7 thing has gone wrong 
which leads him to react in an anti-social way in situations which stimulate others to contructive actions" (El-Awa 1982, 34-35). Pernyataan el-Awa ini tampak akan arti pentingnya reformasi dalam penjatuhan sebuah hukuman.

Paradigma atau teori inilah yang kemudian banyak mewarnai sistem hukum pidana yang berlaku di hampir semua negara Barat dewasa ini. Kendati secara teoritis teori hukuman ini masih dalam perdebatan antara yang pro dan kontra, banyak negara Barat cenderung kepada filsafat hukuman seperti ini.

Konstruksi epistemologis yang demikian, akan berimplikasi pada perubahan teori penjatuhan hukuman. Artinya, dewasa ini bentuk-bentuk hukuman tidak lagi berupa siksaan badaniyah (corporal punish $\neg$ ment) melainkan penjatuhan hukuman lebih terpusat pada perbaikan dan pengobatan pelaku kejahatan. Terkait syarat hukuman yang harus disaksikan banyak orang sejatinya meniscayakan pesan pendidikan dan mem $\neg$ berikan efek jera bagi masyarakat serta arti penting trans $\neg$ paransi penjatuhan hukuman dalam Islam. Dan hal ini merupakan hak ter $\neg$ besar dan terpenting bagi manusia sebagai lawan dari ampunan hakim dan hukum (Syahrur n.d., 225).

Melalui perumusan ulang teori pemidanaan dalam hukuman hudūd, maka upaya yang berkaitan dengan reaktualisasi hukuman hudūd dalam hukum pidana Islam dapat diselesaikan secara arif. Upaya ini dalam hemat penulis dinilai sangat relevan utamanya dengan penghadapan antara hukum pidana Islam dan sistem dan tatanan baru sekarang ini. Dengan demikian, dalam konteks pembaruan hukuman hudūd, kajiannya tidak lagi difokuskan pada hukuman yang kejam dan sadis. Melainkan dengan cara memformat ulang teori hukuman (rekonstruksi) dalam hukuman hudūd untuk disesuaikan dengan lingkungan masyarakat Indonesia yang plural dan terdiri dari berbagai macam agama, nilai kultur yang dianut.

\section{Menemukan Profanitas dengan Pendekatan Kritis}

Secara yuridis politik hukum Indonesia yang berdasarkan Pancasila menghendaki berkembangnya kehidupan beragama dan hukum agama dalam kehidupan hukum nasional. Garis-garis Besar Haluan Negara (GBHN) di bidang hukum menghendaki terciptanya hukum baru di Indonesia yang sesuai dengan cita-cita hukum Pancasila dan UUD 1945, serta yang mengabdi pada kepentingan nasional. Hukum nasional yang dikehendaki oleh negara adalah hukum yang 
menampung dan memasukkan hukum agama, dan tidak memuat norma hukum yang bertentangan dengan hukum agama (Ichtijanto 1996, 178-79).

Upaya untuk mentransformasikan Hukum Pidana Islam ke dalam hukum pidana nasional bukanlah pekerjaan yang mudah. Mengapa? Sebab, Indonesia bukan negara agama dan bukan pula negara sekuler. Hukum Pidana Islam berada di tengah antara paradigma negara dan paradigma negara. Walhasil memperjuangkan hukum pidana Islam menjadi hukum nasional menjadi tantangan tersendiri. Kendati demikian, peluang menjadikan hukum pidana Islam tetap terbuka melalui pendekatan multi-disipliner. Pada titikini hukum Islam dapat berkontribusi dan berperan aktif dalam proses pembangunan hukum di Indonesia dengan kontribusi yang nyata apabila perubahan (pembaruan) hukum pidana Islam telah dapat dilakukan. Dengan demikian, dalam rangka mendapatkan gambaran dan merumuskan relevansi hukum pidana Islam dengan pembaruan hukum pidana di Indonesia sangat diperlukan memahami dan merumuskan terlebih dahulu karakteristik-karakteristik hukum Islam.

Pertama, karakter dinamis (murūnah) hukum Islam harus dikembangkan untuk menunjang perkembangan hukum nasional di alam pembangunan hukum di Indonesia ini. Langkah-langkah strategis yang harus ditempuh adalah, pertama, perhatian besar hukum Islam harus ditujukan kepada persoalan-persoalan duniawi yang menggeluti kehidupan bangsa Indonesia dewasa ini. Kedua, upaya penyusunan hukum pidana Islam baru harus dilakukan untuk memberikan pemecahan bagi persoalan-persoalan hidup aktual yang dihadapi sekarang. Untuk merealisasikan idealisasi ini haruslah melakukan revitalisasi metodologi hukum Islam (baca: ushūl al-fiqh) dan diversifikasi teks serta perluasan wilayah ta'wil (ElSaha 2002, 164).

Harus diakui bahwa yang sangat diperlukan dalam konteks mencari relevansi hukum pidana Islam adalah dengan melakukan revitalisasi metodologi keilmuan pidana Islam dengan multi-pendekatan. Melalui pendekatan inilah maka akan diperoleh manfaat yaitu munculnya rumusan hukum pidana Islam yang lebih realistis dan dinamis serta berkarakterkan keindonesiaan.

Realistis karena rumusan hukum pidana Islam tersebut merupakan hasil dialektika penyusunnya dengan realitas sosial yang dihadapi di Indonesia, sedangkan dinamis karena hukum Islam tersebut dapat berkembang dalam sebuah proses yang bersifat cair dan tidak hanya terikat kepada gambaran dunia khayali 
yang menurut teori "tercipta di masa lampau". Berkarakterkan Indonesia sebab hukum pidana yang dihasilkan lebih berkarakterkan keindonesiaan, tidak Arabic minded yang banyak dirumuskan fuqaha klasik dan tradisional yang dalam epistemenya banyak dipengaruhi bayang-bayang teks-teks keagamaan.

Untuk tujuan pengembangan pengembangan semacam inilah serta dalam rangka transformasi hukum pidana Islam menjadi hukum nasional, maka pandangan yang jauh harus dimiliki oleh para teoritisi hukum Islam. Selain itu, pendekatan multi dimensional dalam kehidupan harus pula dimiliki oleh para teoritisi hukum Islam. Lebih jauh, keterikatan para teoritisi hukum Islam seharusnya tidak hanya kepada dimensi normatif yang telah mengendap sekian lama bahkan hampir-hampir menjadi fosil yang mati (A. Wahid 2007, 50). Pendekatan semacam ini menjadikan usaha-usaha penyegaran hukum pidana Islam, agar tidak lagi memiliki watak sektarian yang akan berhasil menyegarkan satu dua aspek kehidupan belaka karena pendekatannya yang berdimensi tunggal.

Tidak mengherankan jika dalam perjalanan sejarahnya, tepatnya pada awal abad ke-20 di Indonesia muncul gagasan mewujudkan fiqh madzhab nasional. Gagasan ini diusung oleh Hazairin (1905-1975) dengan ide "fiqh madzhab nasional" dan Hasbi as-Shiddieqy (1906-1075) dengan ide "fiqh berwawasan Keindonesiaan". Kedua pembaru tersebut memandang perlu membangun fiqh berkarakter ke-Indonesiaan. Sebab, selama ini fiqh yang berkembang di Indonesia banyak diwarnai fiqh Hijaz, fiqh Mishri, fiqh Hindi yang karakteristiknya jauh berbeda dengan masyarakat Indonesia. Gagasan yang diusung kedua pembaru di atas, tampaknya telah memberikan angin segar bagi pembaruan hukum pidana Islam di Indonesia. Kebutuhan akan hukum Islam berwawasan Indonesia berhasil diwujudkan oleh pemerintah Indonesia. Lahirnya Undang-undang No. 1 tahun 1974, Kompilasi Hukum Islam (KHI) dan lain-lainnya dinilai sebagai hukum Islam model Indonesia (Lukito 2002, 70-72). Inilah fenomena unik yang terjadi di Indonesia dalam rangka mewujudkan hukum Islam berwawasan Indonesia. Diakui, terdapat ketentuan-ketentuan hukum yang berani ketentuan yang agak berbeda dengan ketentuan normatif Alqur'an.

Singkat kata, uraian di atas meneguhkan akan keterbatasan-keterbatasan hukuman pidana Islam yang dirumuskan fuqaha' klasik dalam menghadapi tantangan modernitas dan perubahan sosial yang mengalir begitu cepat. Dan 
apabila tetap mempertahankan rumusan klasik tersebut maka hukum pidana Islam utamanya hudūd akan kehilangan progresivitasnya.

Harus diakui, dunia dan utamanya Indonesia tengah berhadapan dengan tantangan kejahatan yang luar biasa yang mengancam keutuhan sosial, kenyamanan, keamanan dan sebagainya. Fenomena kejahatan pekerja seks komersil (PSK), kejahatan korupsi, gerakan separatisme dan makar, kejahatan pencucian uang (money laundry), perusakan lingkungan dengan pembakaran hutan, pembalakan hutan secara liar (illegal loging), kejahatan dunia maya, narkoba, pembegalan massif dan lainnya merupakan bentuk-bentuk kejahatan kontemporer yang melanda bangsa Ini. Menghadapi semua tantangan di atas, hukum pidana Islam dituntut responsif sebagai pranata yang mampu mengatasi semua kejahatan dalam koridor al-amru bi al-ma'rūf wa al-nahyu 'an al-munkar. Prinsip-prinsip moral inilah yang akan tetap kokoh dan tidak akan pernah usang dimakan perubahan ruang dan waktu.

Analisis tersebut sejatinya menunjukkan bahwa hukum pidana Islam lahir dari hasil dialektika antara kehendak Allah dan kebudayaan manusia (M. A. Abdullah 2000, 6-7). Sebagai produk dialektis, karena itu, sangat wajar jika kenyataan ini kemudian mendorong sebagian ahli menghendaki agar dimensi partikular yang ada dalam hukum pidana Islam dibedakan dari dimensi universalitasnya. Inilah yang kemudian melahirkan diskursus normativitas dan historisitas dalam Islam. Wajar apabila Islam sebagai risalah terakhir mempunyai dua watak ganda. Artinya, pada satu sisi hukum pidana Islam berwatak abadi (tsawābit) yang sakral sebagai wahyu Tuhan (Coulson 1971, 3). Namun pada sisi lain, Islam juga berwatak profan (mutaghayyirāt) dinamis dengan perubahan ruang dan waktu. Watak kedua lebih didasarkan kreasi manusia (ijtihād) dalam merespons dinamika kehidupan manusia hukum Islam selalu membumi dan mampu merespon segala perubahan. Watak yang kedua inilah yang perlu diungkap dan dijadikan pijakan dalam membumikan hukum pidana Islam.

Dengan demikian, pengungkapan dan pemunculan filosofi atau tujuan-tujuan syari’ah (maqāshìd al-syari’ah) serta pengembangan nilai-nilai dasar dalam kehidupan masyarakat dan negara menjadi agenda mendesak untuk dijadikan basis dan acuan dalam pelaksanaan ajaran-ajaran Islam yang bersifat partikular seperti halnya ketentuan hukum pidana Islam. Ini menjadi penting sebab implementasi dan transformasi hukum pidana Islam dirasakan sangat sulit terwujud di Indonesia 
yang serba plural. Oleh karena itu, implementasi hukum pidana Islam ditempuh secara esensial dengan mengacu pada maqāshīd al-syarīah menjadi alternatif realistis di Indonesia. Bahkan, langkah ini dapat menjadi "titik temu" antara aspirasi kelompok fundamentalis yang begitu menginginkan pelaksanaan ajaran pidana Islam utamanya hudūd secara total (komprehensif) dalam kehidupan masyarakat dan negara, dengan (versus) kelompok sekuler atau bahkan "liberal" yang menginginkan pelaksanaan ajaran (hukum) pidana Islam hanya berlaku dalam ranah privat dan menolak keterlibatan dan campur tangan negara dalam wilayah agama.

Selanjutnya, apabila ditelaah lebih dalam lagi, bentuk-bentuk hukuman (pidana) dalam Islam sejatinya merepresentasikan semangat keadilan dan kesataraan dalam hukuman. Standar dan syarat dalam penjatuhan hukuman demikian ketat dan detail. Artinya, jangan sampai hukuman tersebut dijatuhkan secara serampangan dan sembarangan. Inilah yang kemudian meniscayakan ketiadaan syubhat (kesamaran) dalam eksekusi hukuman dalam hukum pidana Islam. Terma syubhat (kesamaran) dalam pengamatan penulis tidak hanya bermakna terpenuhinya syarat dan unsur-unsur inhern dalam tindak pidana zina, seperti keharusan empat orang saksi, dilakukan di depan publik dalam perzinaan. Demikian hanya syarat mencapai nishab dalam pencurian dan lain sebagainya. Namun syubhat juga mencakup aspek-aspek eksternal seperti kondisi ekonomi, sosial dan politik yang juga menentukan aplikatif tidaknya ketentuan hudūd dalam Islam. Sebagaimana sejarah mencatat ijtihad 'Umar yang tidak memotong pencuri pada saat atau musim kelaparan (Al-Jauziyyah 1991, 22).

Pada titik ini, pembaru dari Mesir M. Said al-'Ashmawi mengajukan proposisi bahwa ketentuan pidana pasti (fixed punishment) dalam hukum pidana Islam hanya relevan dan aplikatif pada masyarakat yang memiliki keimanan kuat, rasa keadilan yang tinggi, bertaqwa kepada Allāh dan masyarakat yang menjunjung tinggi kebenaran sehingga hukuman hudūd tidak digunakan untuk tujuan-tujuan yang tidak sejalan dengan nilai-nilai syari’ah. Pendeknya, jangan sampai hukuman hudūd dijatuhkan pada situasi masyarakat yang penuh dengan kesaksian palsu, penuh konspirasi hukum dan peradilan yang masih dipengaruhi politik. Sebelum hukum hudūd mau diaplikasikan, maka yang perlu diperkuat terlebih dahulu keimanan dan ketaqwaannya. Hal ini sesuai dengan prinsip graduasi dalam penurunan ayaat-ayat hudūd dalam hukum Islam. Graduasi hukum menghendaki 
kondisi masyarakat siap secara keimanan dan ketaqwaan (Al-Asmawi 2012, 12021).

Prinsip kedua yang melekat dalam hukum pidana Islam yaitu prinsip taubat. Unsur taubat mampu mencegah eksekusi hukuman dalam doktrin hukum pidana Islam. Hampir semua ketentuan hudūd selalu dikaitkan dengan pentingnya aspek pertaubatan. Dari sini dapat dijelaskan bahwa tujuan utama dalam hukum pidana Islam adalah fungsi rehabilitasi. Fungsi rehabilitatif juga dikenal dalam kajian ilmu kriminologi modern. Dalam perspektif rehabilitatif, dinyatakan bahwa kesalahan dan kejahatan individu itu bersifat juga kesalahan kolektif. Manusia mencuri bukan karena semata kesalahan yang bersangkutan, tetapi hal itu juga didorong oleh sistem sosial ekonomi yang membuat seseorang melakukan perbuatan pencurian. Dengan demikian, tugas pemidanaan dalam pemikiran penologi kontemporer adalah menormalkan kembali si pelaku kejahatan sehingga tidak hanya terfokus pada penjeraan dengan hukuman-hukuman bersifat fisik (badani). Dalam perspektif demikian, sejatinya tidak ada istilah penjara, tetapi yang ada adalah lembaga pemasyarakatan.

Prinsip lainnya dalam hukum pidana Islam adalah meringankan hukuman dari bentuk-bentuk hukum sebelumnya. Demikian halnya dengan prinsip rafu al-haraj (menghilangkan kesulitan) merupakan karakter-karakter bahwa hukum pidana Islam dalam konteks keindonesiaan sangat aplikatif bahkan terbuka dengan upayaupaya pembaruan. Dengan melakukan pendekatan-pendekatan semacam ini maka ketentuan hukum pidana Islam mampu membumi di bumi Nusantara.

Untuk mewujudkan tujuan luhur tersebut, kajian hukum pidan Islam dalam bingkai Islam idealnya tidak hanya berkutat dan terjebak pada persoalan bentukbentuk hukumannya yang dipandang final. Melainkan bagaimana bingkai etikamoral dan semangat yang terkandung dalam hukum pidana Islam dikembangkan dalam konteks keindonesiaan sebagai benteng perlindungan masyarakat dari segala bentuk kejahatan.

Oleh karena itu, dalam kaitannya transformasi hukum pidana Islam ke dalam hukum nasional, penulis menawarkan beberapa langkah strategis yaitu: pertama, umat Islam harus berusaha terus menerus menangkap dan memenangkan spirit (semangat) dalam pidana Islam. Dengan tujuan supaya ia tetap relevan dengan perkembangan zaman tanpa harus secara formal memproklamirkan diri dengan penerapan syariat Islam. Sebab, mendeklarasikan pemberlakuan syariat Islam 
justru hanya akan menjadi bumerang bagi umat Islam sendiri. Utamanya pasca dikumandangkan formalisasi ketentuan hukum pidana Islam itu sendiri, tingkat korupsi masih tinggi, kesenjangan sosial masih tinggi dan masyarakat tidak merasakan bedanya dan tidak merasakan situasi yang lebih adil dan sejahtera. Singkat kata, dalam konteks Indonesia, yang ditransformasikan adalah prinsipprinsip umum dalam syariat yang bisa membawa kemaslahatan bagi semua golongan. Sehingga maka aplikasi pidana Islam tidak akan menimbulkan masalah.

Lebih dari itu, apabila umat Islam mau menerapkan dan memformalkan hukum pidana Islam peninggalan masa lalu maka mereka harus berani melakukan reformasi dan reinterpretasi terhadap bagian-bagian yang sudah tidak relevan dengan perkembangan masa kini agar bisa diterima dan kiranya dapat mendatangkan maslahat bagi semua orang.

Kedua, dalam upaya-upaya transformasi hukum pidana Islam selain menggunakan pendekatan filosofi (maqāshīd al-syarı̄ah) sebagai acuannya, juga sangat diperlukan pelibatan akal publik. Akal publik adalah bentuk keterlibatan masyarakat melalui mekanisme musyawarah (rule of law) sebagai manifestasi pendekatan kritis. Sebab, dalam negara demokratis seperti Indonesia, setiap Muslim sesungguhnya mempunyai kesempatan dan peluang yang setara, yakni untuk menerjemahkan dan membumikan hukum-hukum Allāh . Sebab, ijtihad bukan saja menjadi otoritas para fuqaha' dan penguasa saja yang sering mengatasnamakan diri mereka sebagai khalifatullah sebagaimana yang sering dipahami selama ini. Dengan demikian, idealnya ijtihad merupakan refleksi pemikiran dinamis manusia yang pada akhirnya mengarah pada konsensus atau kesepakatan. Sebagaimana Fazlur Rahman mengatakan: "ijtihad must be multiple effort of thinking minds --some naturally better than other , and some better than other in various areas-- that confront each other in open arena of debate, resulting eventually in an overall consensus (Rahman 1979, 325). Ijtihad merupakan berbagai upaya mengerahkan segala bentuk pemikiran, yang secara alami ijtihad satu akan lebih baik dengan lainnya, dan ijtihad dala suatu wilayah mungkin lebih baik dari yang lain, --yang meniscayakan perbedaan satu dengan lainnya di arena perdebatan terbuka, sehingga menghasilkan konsensus secara keseluruhan.

Melalui pendekatan dan strategi demikianlah akan mampu mendialekkan antara pengetahuan dengan kepentingan masyarakat. Artinya, terdapat koneksi antara teori dengan kenyataan melalui upaya refleksi diri yang tidak pernah 
berhenti sehingga masyarakat terbebas dari belenggu-belenggu dogma, ideologi dan dominasi yang lahir dari luar diri manusia itu sendiri (Fanani 2010, 214). Dengan pendekatan dan pemikiran keagamaan baru ini pada saat yang sama dapat membuka suatu dialog baru yang penting antara hukum pidana Islam dengan hukum HAM internasional. Dialog seperti ini akan dapat membantu dalam mengembangkan suatu konsensus bersama. Dialog semacam ini juga pada gilirannya secara cepat atau lambat dapat menghilangkan sikap antipati terhadap hukum pidana Islam utamanya rumusan hudūd yang dipandang hukum yang kejam dan sadis. Dan, apabila situasi demikian terus berlangsung, akan menciptakan suasana yang ramah bagi ruang dialog antara hukum pidana Islam, perundang-undangan positif, dan realitas kekinian secara objektif, partisipatif, demokratis dan tidak terbayang-bayangi oleh beban sejarah. Inilah yang disebut pendekatan atau teori kritis. Pendekatan ini akan melahirkan masyarakat yang emansipatoris dan terbebas dari segala bentuk dan dominasi dan hegemoni.

Walhasil strategi penggunaan teori kritis ini diyakini mampu menghasilkan kebenaran yang tidak lagi bersifat objektif-positivistik, melainkan kebenaran yang bersifat konsensus dari berbagai lapisan masyarakat. Hal ini terjadi karena dalam teori kritis tidak hanya menjadikan para fuqaha', kaum ilmuan dan penguasa (politisi) sebagai pemain utama (play maker) melainkan memposisikan dan melibatkan masyarakat secara keseluruhan sebagai pemain utama dan pembentuk hukumnya sendiri.

\section{Kesimpulan}

Berdasarkan uraian dan analisis di atas dapat diambil beberap kesimpulan sebagai berikut: pertama, terdapat sejumlah variabel yang menjadi hambatan transformasi pidana Islam ke hukum nasional yaitu: budaya, sosial dan problem keilmuan yang belum selesai di kalangan ahli terkait hukuman-hukuman pasti dalam pidana Islam; kedua, secara keilmuan para ahli dalam memandang materi hukum pidana Islam terdiametral dalam dua kutub. Sebagian memandang hukum pidana Islam dengan beberapa bentuk pidanya bersifat pasti dan sakral dengan demikian ia konstan dan sebagian lagi memandang rumusan pidana Islam merupakan entitas yang terbuka dengan pembaruan; dan ketiga, metode yang tepat dalam memformalkan pidana Islam adalah dengan "membangun ulang" rumusan keilmuan pidana Islam yang berkarakterkan keindonesiaan dan pada saat 
yang sama harus memanfaatkan nalar kritis yang meniscayakan pelibatan akal publik dan pendekatan multidisipliner sehingga ia menjadi relevan untuk menjadi hukum nasional.

\section{DAFTAR PUSTAKA}

Abdillah, Masykuri. 1999. "Posisi Hukum Pidana Islam Dalam Konteks Politik Hukum Dan Perundangan Indonesia." In Hukum Pidana Islam: Deskripsi, Analisis Perbandingan, Dan Kritik Konstruktif, Jakarta: Fakultas Syariah IAIN Syarif Hidayatullah Jakarta.

. 2011. Islam Dan Dinamika Sosial Politik Di Indonesia. Jakarta: PT Gramedia Pustaka Utama.

Abdullah, Abdul Gani. 2011. "Eksistensi Hukum Pidana Islam Dalam Reformasi Sistem Hukum Nasional.” In Pidana Islam Di Indonesia: Peluang, Prospek, Dan Tantangan., Jakarta: Pustaka Firdaus.

Abdullah, Muhammad Amin. 2000. "Rekonstruksi Metodologi Studi Agama Dalam Masyarakat Multikultural Dan Multirelijius." In Antologi Studi Islam; Teori Dan Metodologi, Yogyakarta: UIN Sunan Kalijaga Press.

Abu Hapsin. 2019. "No Title." http//www.kemenag.go.idacis11filedokumene2.AbuHapsin.pdf.

Al-Asmawi, Muhammad Sa'id. 2012. Penerapan Syariat Islam Dalam UndangUndang; Belajar Pengalaman Dari Mesir. Jakarta: Referensi.

Al-Jabiri, Muhammad Abid. 2001. Agama, Negara, Dan Penerapan Syariah. Yogyakarta: Fajar Pustaka Baru.

Al-Jashshash, Abi Bakr Ahmad al-Razi. 1993. Ahkām Al-Qurāān. Beirut: Dar alFikr.

Al-Jauziyyah, Ibn al-Qayyim. 1991. I'lām Al-Muwaqqi'in 'An Rabb Al-'Alamīn Jilid 2. Beirut: Dar al-Kutub al-'Ilmiyyah.

Al-Jurjani, Abi al-Hasan al-Husaini. 1938. Al-Ta'rifät. Mesir: Musthafa al-Babi alHalabi.

Al-Mawardi, Ali ibn Muhammad ibn Habib. Al-Ahkām Al-Sulthaniyyah. Beirut: Dar al-Kitab al-'Arabi.

Al-Munawar, Said Agil Husin. 2004. Hukum Islam Dan Pluralitas Sosial. Jakarta: Penamadani.

Al-Qurthubi. Al-Jami' Li Ahkam Al-Qurr'an. Beirut: Dar al-Kurub al-'Ilmiyyah. 
Al-Syaukani, Muhammad ibn Ali. 2009. Irsyād Al-Fuhūl Ilā Tathbīqi Al-Haqqi Min 'Ilmi Al-Ushūl. Kairo: Dar al-Salam.

Ali. 2014. “Pengaruh Tradisi Arab-Pra Islam Terhadap Hukuman Rajam.” Jurnal Ilmiah Islam Futura 14(1).

An-Na'im, Abdullahi Ahmed. 1996. Toward an Islamic Reformation, Civil Liberties, Human Rights and International Law. New York: Syracuse University Press.

Arifin, Bustanul. 1996. Pelembagaan Hukum Islam Di Indonesia: Akar Sejarah, Hambatan Dan Prospeknya. Jakarta: Gema Insani Press.

Asshiddiqy, Jimly. 1996. Pembaharuan Hukum Pidana Indonesia; Studi Tentang Bentuk-Bentuk Pidana Dalam Tradisi Hukum Fiqh Dan Relevansinya Bagi Usaha Pembaharuan KUHP Nasional. Bandung: Angkasa.

Azhari, Muhammad Tahir. 1992. Negara Hukum: Suatu Studi Tentang PrinsipPrinsipnya Dilihat Dari Segi Hukum Islam, Implementasinya Pada Periode Negara Madinah Dan Masa Kini. Jakarta: Bulan Bintang.

Bahansi, Ahmad Fathi. 1961. Al-Uqubat Fi Fiqhi Al-Islami. Kairo: Maktabah Dar al Uqubah.

Beik, Muhammad Khuddlari. 1988. Tarikh Al-Tasyri' Al-Islāmī. Kairo: Tijariyyat al-Kubra.

Coulson, Noel J. 1971. International Affairs Conflicts and Tensions in Islamic Jurisprudence. Chicago: The University of Chicago Press.

_—_ 1987. The History of Islamic Law. Jakarta: P3M.

Djazuli, H. A. 2000. Fiqh Jinayah: Upaya Menanggulangi Kejahatan Dalam Islam. Jakarta: PT Raja Grafindo Persada.

El-Awa, Mohammed S. 1982. Punishment in Islamic Law. Indianapolis: American Trust Publications.

El-Saha, M. Isham. 2002. "Epistemologi Hukum Islam Perspektif NU." Tashwirul Afkar (12).

Fanani, Muhyar. 2010. Metode Studi Islam; Aplikasi Sosiologi Pengetahuan Sebagai Cara Pandang. Yogyakarta: Pustaka Pelajar.

Hossen, Ibrahim. 1990. Pembaharuan Hukum Islam Di Indonesia. Jakarta: CV. Putra Harapan.

Ichtijanto. 1996. "Prospek Peradilan Agama Sebagai Peradilan Negara Dalam Sistem Politik Hukum Di Indonesia.” In Dimensi Hukum Islam Dalam Sistem Hukum Nasional: Mengenang 65 Th. Prof. Dr. H. Busthanul Arifin, S.H, ed. Amrullah Ahmad. Jakarta: Gema Insani Press, 178-79. 
Jaspan, M. A. 1988. Hukum, Politik Dan Perubahan Sosial. Jakarta: YLBHI.

Ka'bah, Rifyal. 1999. Hukum Islam Di Indonesia; Pemikiran NU Dan Muhammadiyyah. Jakarta: Universitas Yarsi.

Karim, Khalil Abdul. 2002. Hegemoni Quraisy: Agama, Budaya Dan Kekuasaan. Yogyakarta: LKiS.

Khan, Juristic. 1983. "Classification of Islamic Law." Houston Journal of International Law 6(23).

Lukito, Ratno. 2002. "Pergumulan Hukum Islam Dan Adat Di Indonesia." In Pranata Islam Di Indonesia; Pergulatan Sosial, Politik, Hukum Dan Pendidikan, eds. Dody S. Truna and Ismatu Ropi. Ciputat: Logos Wacana Ilmu.

Mahendra, Yusril Ihza. 1999. Modernisme Dan Fundamentalisme Dalam Politik Islam: Perbandingan Partai Masyumi (Indonesia) Dan Partai Jama'at-IIslami (Pakistan). Jakarta: Paramadina.

Maksun, Faiz. 2005. "Formalisasi Syariat Islam Dalam Konteks Kekinian." Justisia 28.

Mu'izzuddin, Mochammad. 2019. "Kontribusi Dialek Quraisy Dan Dialek Tamim Terhadap Bahasa Arab Fushha (Kajian Sosio-Psikolinguistik)." http//www.isjd.pdii.lipi.go.id.

Nurrohman. 2012. "Artikulasi Pidana Islam Dalam Ruang Publik: Tinjauan Politik Hukum Islam Atas Kasus Rajam Di Ambon, Putusan Mahkamah Konstitusi No. 19/PUU- VI/2008, Dan Qanun Jinayat Di Aceh.” Jurnal Studi Islam 18(2).

___. 2019. "Qanun Jinayah versus Hukum Nasional: Problematika Formalisasi Hukum Islam Di Aceh.” www.acehinstitute.com.

Paydar, Manouchehr. 2003. Legitimasi Negara Islam: Problem Otoritas Syari'ah Dan Politik Penguasa. Yogyakarta: Fajar Baru Pustaka.

Praja, Juhaya S. 2011. Teori Hukum Dan Aplikasinya. Bandung: Pustaka Setia.

Rahman, Fazlur. 1979. "Islam Challenges and Opportunies." In Islam: Past Influence and Present Challenge, eds. Alford T.Welch and Piere Cachia. Edinburgh: Edinbrugh University Press.

Reksodiputro, Mardjono. 1995. Pembaruan Hukum Pidana. Jakarta: Lembaga Kriminologi UI.

Rofiq, Ahmad. 2001. Indonesia, Pembaharuan Hukum Islam Di. Yogyakarta: Gama Media.

Rosyidi, Rahmat, and M. Rais Ahmad. 2006. Formalisasi Syariat Islam Dalam 
Perspektif Tata Hukum Indonesia. Bogor: Ghalia Indonesia.

Ruysd, Ibnu. Bidayat Al-Mujtahid Wa Nihayah Al-Muqtashid, Juz II. Semarang: Maktabah Urwah.

Sabiq, Sayyid. 1997. Fiqh Al-Sunnah. Mesir: Dar al-Fath li al-I'lam al-Araby.

Santilana, David de. 1952. Law and Society. London: Oxford University Press.

Santoso, Topo. 2010. Membumikan Hukum Pidana Islam; Penegakan Syaiat Dalam Wacana Dan Agenda. Jakarta: Gema Insani Press.

Schacht, Joseph. 1955. Unity and Variety in Muslim Civilazation. ed. Gustav E. Von Grunebaum. Chicago: Chicago University Press.

Soeharno. 2012. "Benturan Antara Hukum Pidana Islam Dengan Hak-Hak Sipil Dalam Perspektif Hak Asasi Manusia." Lex Crimen 1(2).

Syahrur, Muhammad. Prinsip Dan Dasar Hermeneutika Hukum Kontemporer. Yogyakarta: LKiS.

Ukaz, Fikri Ahmad. 1982. Falsafah Al-“Uqūbah Fi Al-Syarî”ah Al-Islāmiyyah Wal Al-Qānūn. Riyadh: Ukadl li al-Nasyr wa al-Tauzi'.

Wahid, Abdurrahman. 2007. Islam Kosmopolitan: Nilai-Nilai Indonesia Dan Transformasi Kebudayaan. Jakarta: The Wahid Institute.

Wahid, Marzuki. 2002. "Syari' at Islam: Antara Pemberlakuan, Formalisasi Dan Politisasi, Bacaan Kritis Atas Wacana Dan Gerakan Syariat Islam Pasca Orde Baru." In Dari Gontor Ke Pulau Buru, Yogyakarta: Syarikat.

Zahrah, Muhammad Abu. 1997. Al-Islam Wa Taqnin Al-Ahkam.

___ . 1998. Al-Jarimah Wa Al-Uqubah Fi Fiqh Al-Islami. Kairo: Dar al-Fikr al-'Arabi.

'Audah, Abd al-Qādir. 1996. Al-Tasyrī' Al-Jinā'î Al-Islamī Muqāranan Bi AlQānūn Al-Wadl'ì. Beirut: Mu’assasah al-Risalah. 